\title{
地域空間の確率論的地震動ハザード評価手法の提案と地震防災への活用について PROPOSAL OF SPATIAL PROBABILISTIC SEISMIC HAZARD ANALYSIS
AND THE APPLICATION TO THE DISASTER PREVENTION
}

林孝幸*1, 矢代晴 実*2

Takayuki HAYASHI and Harumi YASHIRO

\begin{abstract}
In this study, we propose a spatial probabilistic hazard analysis (PSHA) with spatial correlation and correction based on earthquake observation records. To model the spatial correlation of the ground motion, we estimate spatial correlation statistically using observation dataset in the target area. And, we apply it to a PSHA in conjunction with spatial interpolation of ground motion using the simple kriging method for the correction based on the observation. In a trial application for Kanagawa prefecture, seismic hazard curve for area was calculated to discuss the contribution of this method to regional disaster prevention planning.
\end{abstract}

Keywords: Probabilistic seismic hazard analysis, Spatial correlation, Site correction, Simple Kriging method 確率論的地震動評価, 空間的な相関, 地点補正, Simple Kriging 法

\section{1. はじめに}

近年, 日本では多くの被害地震が発生している。近い将来, 南海 トラフ沿いの大地震や首都直下地震等の発生も懸念されており, 地 震防災対策が急務である。政府や地方自治体の地震被害想定では, 対象とする地域や地点に被害を及ぼす可能性のある地震シナリオを 選定し, 地震動や津波, 液状化等の地震八ザードが決定論的アプロ 一チにより評価される。この地震ハザードを用いて被害を定量化し， 地域防災計画等の施策が検討される。地震八ザード評価は対策の最 初の段階で実施され, 最終的な施策を決定づける重要な役割を有し ており, その結果について十分な議論が必要である。

一方, 平成 23 年 (2011 年) 東北地方太平洋沖地震（以降, 東北 地震と記す）では, 事前にこの規模の地震発生が想定されていなか った。これを教訓として, 今後の地震・津波対策において, 科学的 知見を踏まえ, あらゆる可能性を考慮した最大クラスの巨大な地震・ 津波を検討する事が提案された 1)。現在, 政府の防災基本計画 2)に は, 最大クラスの地震・津波の想定が明記されており, 政府や地方 自治体の地震被害想定ではこれが検討されている。しかし, 想定さ れた最大クラスの地震・津波の地震八ザードは, 地震動が極めて大 きくなるケースや, 津波溯上域が非常に広域になるケースがあり, 有効な対策の立案に苦慮する場面も見られる。最大クラスの地震 津波の発生確率が極めて小さい場合には，これを長期的に対応する 地震と位置付け, より小さい規模の地震や地震八ザードを当面の対 策の対象とする事もなされている。よって, 地震八ザード評価では, 決定論的アプローチだけではなく確率論的アプローチも併用し, そ
の発生確率を把握して妥当性を検証し，対策の必要性を議論する事 が重要と考える。最大クラスの地震を, 最大限の地震八ザードを発 生させる地震と定義すると，その科学的検証が困難であるため，過 度に保守的な設定になる事を眯念寸る。筆者らは最大クラスの地震 は，地震八ザードと一体的に捉え，特定の低い確率で発生する地震 ハザードという定義に基づいて設定されるべきと考える。もちろん， その確率值の設定について慎重かつ十分な議論が必要である。以降 では, 多様な地震八ザードの内, 対象を地震動に限定して議論する。 建築物の設計用地震動の策定においては，決定論的と確率論的な アプローチの双方により地震動評価を行い検証する事が議論されて いる。建築物荷重指針・同解説(2015)3)では, 両アプローチを併用す る事で設計用地震動の設定根拠の議論が深まるとされている。また, 米国では, 東北地震による福島第一原子力発電所の事故発生を受け て, 地震動ハザードカーブから求めた地震動（GMRS：Ground Motion Response Spectrum) と設計用の地震動（SSE：Safe Shutdown Earthquake)を比較し, 原子力施設の安全性を議論する 取組みも行われている4)。しかし，これらは特定の地点における取 組である。地方自治体の地震防災等, 広域の地震動ハザードを検討 する際は，地域内で被害を及ぼす強震動の広域性が対策を計画する 上での重要な観点となる。広域災害と局地的な災害では地方自治体 の対応策も異なる。また，近年の被害地震では，交通施設や企業の 事業活動におけるサプライチェーン等, 面的に分布する施設の被害 が，波及的に被害を拡大させる事態も注目されており，地震動ハザ ードを面的に捉える必要性が増している。地震調査研究推進本部が

\footnotetext{
*1＼cjkstart東京海上日動リスクコンサルティング侏企業財産本部 ユニットリーダー・工修

*2 防衛大学校システム工学群建設環境工学科 教授・博士 (工学)
}

Unit Leader, Property Risk Engineering Dept., Tokio Marine \& Nichido Risk Consulting Co., Ltd., M.Eng.

Prof., Dept. of Civil \& Environmental Engineering, School of Systems Engineering

National Defense Academy of Japan, Dr.Eng. 
公開する確率論的地震動予測地図 ${ }^{5)}$ は, 日本全土を約 $250 \mathrm{~m}$ 平方の メッシュに離散化し, そのメッシュ中心点において確率論的地震動 八ザードを評価している。しかし, 各地点の評価結果は空間的に独 立である。地域空間を対象に確率論的評価を行う場合, 空間的な地 震動の相関を考慮することが必要であるが, そのような確率論的地 震動ハザード解析手法や結果の表現方法は十分に議論されていない。 また, 確率論的地震動ハザード評価で採用される経験的距離減衰式 は様々な地点における観測記録から回帰的に構築された地震動予測 手法であり，評価地点の観測記録を用いて予測式の補正を行うこと で, その地点の地震環境や地盤増幅等のサイト特性を反映できる例え ば6)。しかし, 評価対象が地域空間である場合には, 全メッシュの観 測記録がないため, そのような補正を行う事は困難である。

これまでにも空間的な地震動の相関を確率論的に検討した研究は 実施されている。筆者ら $(2006)^{7)}$ は, 観測記録の分析によりモデル化 した空間的な地震動の相関を, 複数地点の建物から構成される建物 ポートフォリオの確率論的地震リスク評価手法に適用した。防災科 学技術研究所による検討(2018) 8) は, 空間的な地震動の相関による 被害量の相関をモデル化し, 確率論的に被害を評価した。これらの 検討は結果として被害量を示すもので, 対象地域の地震動八ザード の確率特性は議論していない。一方, 能島ら 9)は, 統計的グリーン 関数法により複数の震源パラメータを用いて算出した地震動分布を 特異值分解法によりモード分解し, 各モードの物理的説明を行った。 また, 各モードを確率的に合成する地震動評価手法を提案し, 算出 した地震動分布により多様な被害分布を評価できることを示した。 地域における総被害量の妥当性を丁寧に検証するためには, その被 害量を説明する地震動ハザードを確認することが重要と考える。

地震動の空間相関を考慮した確率論的な評価では, 対象空間にお ける地震動強度の推定誤差に関する分散共分散マトリクスをコレス キー分解し, モンテカルロシミュレーションにより評価する手法が 採用される7)。しかし, 対象が広域になると, 分散共分散マトリク スも大規模となり計算負荷が高くなる。そこで, 安部ら ${ }^{10)} は$, 広域 災害となる大規模地震を対象に, 空間的な相関を表す大規模な分散 共分散行列を疎行列化して計算負荷を軽減する方法を提案した。能 島ら 9)の手法も計算量の低減効果が大きい。広域を対象とする場合 や地震シナリオが大多数の場合は, 計算量の低減が重要である。

本研究では, 地域空間の確率論的地震動評価手法 (以降, SPSHA: Spatial Probabilistic Seismic Hazard Analysis と記す) を提案す る。筆者ら 7)が提案した地震動の空間的な相関モデルについて, 地 震動強度指標を変更し, 最新の地震観測記録を用いて再構築する。 次に, これを計算量の削減も念頭において SPSHA に適用する手法 を提案する。この時, 観測記録に基づく地震動予測の補正も考慮す る。そして, 神奈川県を対象に本手法を適用し結果を検討する。ま た, 地域の被害想定の妥当性の検証や最大クラスの地震の設定等, 地域防災における活用について検討する。

\section{2. 地震動強度の空間的な相関の評価}

\section{1 評価方法}

地震動の空間的な相関を論じる指標は, 筆者ら7) と同様に観測記 録と地震動予測式による推定值との推定残差 $\varepsilon$ 用いる。 と地点の影響の双方を含むため, これらを次式のように除去する。

$$
\begin{aligned}
& \varepsilon_{c_{i j}}=\log \left(o_{i j} / c_{i j}\right)-\alpha_{i}-\beta_{j} \\
& \varepsilon_{c_{i k}}=\log \left(o_{i k} / c_{i k}\right)-\alpha_{i}-\beta_{k}
\end{aligned}
$$

ここで， $\varepsilon_{c}$ は地震と地点の影響を除いた推定残差，oは観測值，cは 経験的距離減衰式による推定值, $\alpha$ は地震補正係数, $\beta$ は地点補正係 数である。添え字のiは地震を, $j$ と $k$ は地点を表す。地点 $j$ とにおけ る地震動強度の空間的な相関は, (1),(2)式の推定残差 $\varepsilon_{c}$ を用いて次 式で算定する。

$$
\rho_{j k}=\frac{\frac{1}{n-1} \sum_{i=1}^{n}\left(\varepsilon_{c_{i j}}-\mu_{j}\right)\left(\varepsilon_{c_{i k}}-\mu_{k}\right)}{\sigma_{j} \sigma_{k}}
$$

ここで, $n$ は地点 $j$ とにおいて共通に観測した地震数である。 $\mu_{j}$ と $\sigma_{j}$ は $\varepsilon_{c_{i j}}$ の平均と標準偏差, $\mu_{k}$ と $\sigma_{k}$ は $\varepsilon_{c_{i k}}$ の平均と標準偏差である。 なお，(1)式の $\alpha$ と $\beta$ は次式を最小化する回帰係数として算定する。

$$
\alpha_{i}+\beta_{j}=\log \left(o_{i j} / c_{i j}\right)
$$

\section{2 地震動データセットの構築}

本検討では, 対象地域の地震動の観測記録から統計的に地震動の 空間相関をモデル化する。後述の試算では, 神奈川県を対象として 評価を実施するため, 以下のように地震動データセットを構築した。

\section{（1）地震の選定}

対象地震は防災科学技術研究所が運営する地震観測網K-NETと KiK-net ${ }^{11)}$ で観測されたものとし, 主に構造物に被害を与えるよう な地震動を対象とすることを念頭に，以下の条件を設定した。

対象地震 : 神奈川県内の観測点で震度 4 程度以上を観測した地震 地震規模 : 気象庁マグニチュード $(\mathrm{Mj}) 5.0$ 以上

観測期間：1996年9月 2018年6月

震源位置（緯度, 経度, 震源深さ）の情報は, 気象庁による一元 化処理結果12)を用いた。一元化処理が未実施の一部の地震について は，観測記録のヘッダ情報に記載された速報值を用いた。地震動予 測に用いるモーメントマグニチュード $(\mathrm{Mw})$ は, 気象庁のCMT解 による評価值13)を用いた。気象庁による CMT解が未公開の一部の地 震は, 防災科学技術研究所の広帯域地震観測網F-net ${ }^{14)}$ で公開されて いる自動メカニズム解推定結果による Mwを用いた。両者でも公開 されていない場合は, 防災科学技術研究所の検討15) (以降, NIED検 討と記す) に従って, 海溝型地震は $\mathrm{Mw}=\mathrm{Mj}$, 内陸地殼内地震は武村 16)に基づき $\mathrm{Mj}$ から Mwを求めた。また, NIED検討では, 地震活動度 のモデル化のために, 地震カタログの各地震の震源位置（緯度, 経 度, 深さ) と各プレートの位置関係から地震タイプ (内陸地款内, プレート境界, プレート内）を設定している。本検討でも, 同様の 方法で地震タイプを設定した。但し, 設定した地震タイプと気象庁 CMT解および震源位置等の情報を精查し, 明らかに地震タイプが異 なると判断される一部の地震は, 個別に再設定した。

Fig.1に上記の条件を満たす地震の震央分布 (全196地震) を示す。 また, Fig.2に地震のマグニチュードの頻度と震源深さの分布を示す。 選定した地震は, 内陸地殼内が 53 , プレート境界が 27 , プレート内 が116であった。プレート境界地震は太平洋プレート, フィリピン海 
プレートの両プレートについて選定されている。最大規模の地震は, 東北地震(Mw9.0)であり, 選定された地震は東北地震の余震域で発 生した太平洋プレートのプレート内地震が多い。内陸地殼内の地震 は新潟県や福島県周辺を震源とする地震が多く選定された。震源深

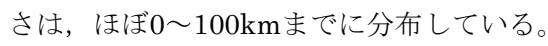

\section{（2）地震動データセット}

選定した地震についてK-NET, KiK-netの地表の観測記録を収集 した。観測記録は 7,136 記録あり，東北地方や関東地方の 1,316 観測 点で観測されたものであった。本検討で地震動の空間的相関を検討 する地震動指標は工学的基盤（ $\mathrm{S}$ 波速度： $\mathrm{Vs}_{\mathrm{S}}=400 \mathrm{~m} / \mathrm{s}$ 程度）における 最大速度 (PGV) とする。地表のPGVは, 地表におけるNS/EWの各 方向の記録に対してフィルタ処理した上で一階積分し, 水平方向に 合成したベクトルの最大振幅值とした。工学的基盤のPGVは, NIED 検討と同様に藤本・翠川(2006) ${ }^{177}$ に基づき, 表層 $30 \mathrm{~m}$ の平均 $\mathrm{S}$ 波速度 (AVS30)から推定された地盤増幅率により除して求めた。このよう に求めた工学的基盤のPGVは, 約 $1.0 \sim 100 \mathrm{~cm} / \mathrm{sec}$ の範囲に分布して いる。観測記録には, 大速度の地震動があり地盤の塑性化の影響も 考えられるが，そのような記録は全体数に対して少ないと考え，振 幅の程度によらず一定の地盤増幅率を採用した。

\section{3 地震補正係数と地点補正係数の算出}

(4)式に示した地震 $i の$ 観測地点 $j$ におけ観測值 $o_{i j}$ は前節の地震 動データセットの工学的基盤におけるPGVとする。また, 計算値 $c_{i j}$

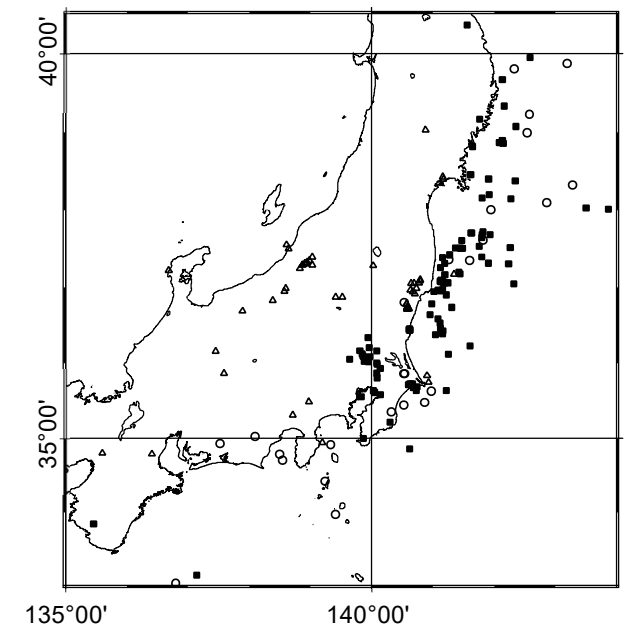

O Inter-plate EQ $\quad$ Intra-plate EQ $\triangle$ Crustal EQ

Fig.1 Seismic source for this study
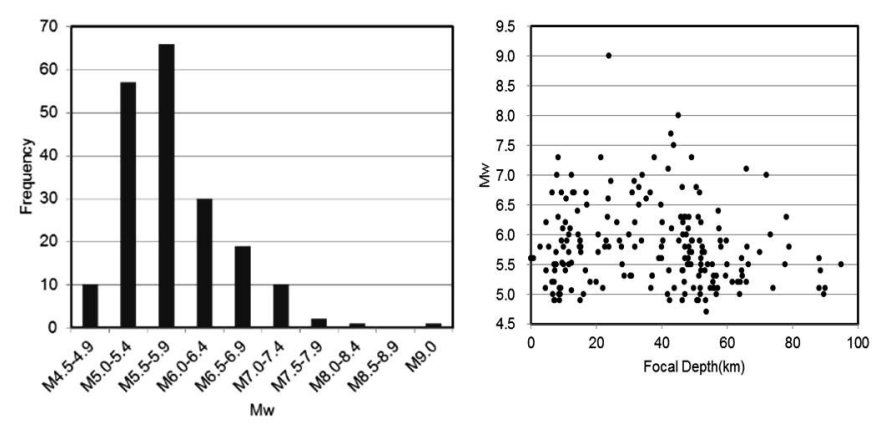

Fig.2 Histogram for magnitude and Distribution of focal depth
は，NIED検討と同様の手法にて算出する工学的基におけるP $G V_{b 400}$ とする。以下に, この手順を示す。最初に (5)式に示寸司・翠川 (1999) 18)が提案した経験的距離減衰式 (以降, 司・翠川式と記す) により, $\mathrm{Vs}=600 \mathrm{~m} / \mathrm{s}$ 相当の基盤における $P G V_{b 600}$ を算出する。

$$
\begin{aligned}
& \log P G V_{b 600}=0.58 M_{W}+0.0038 D+d_{k} \\
& \quad-1.29-\log \left(X+0.0028 \cdot 10^{0.5 M_{w}}\right)-0.002 X
\end{aligned}
$$

ここで, Xは断層最短距離 $(\mathrm{km})$ である。断層最短距離は, 震源位置 と観測地点間の距離とする。但し, 東北地震については震源領域が 広域であるため, NIED検討の震源モデルの内, 東北地方太平洋沖 型地震の震源域からの最短距離とした。また, Dは震源深さ $(\mathrm{km})$, $M_{W}$ はモーメントマグニチュードである。 $M_{W}$ は 8.3 を上限とする。 $d_{k}$ は地震タイプ $k$ ごとに求められた回帰係数を示す。なお, 太平洋プレ ート沿いで発生する一部の地震については, NIED検討に基づき, 東北日本の異常震域補正を考慮する。

工学的基盤でのP $G V_{b 400}$ は, 藤本・翠川(2006) ${ }^{17)}$ の提案するPGVの 地盤増幅率の評価式でAVS30を $400 \mathrm{~m} / \mathrm{s}$ として得られる係数 $1.41 を$ $P G V_{b 600}$ に乗じることで算出する。

(4)式について得られた地震補正係数 $\alpha$ と地点補正係数 $\beta$ の分布を Fig.3に示す。 $\alpha$ の平均值と標準偏差は, 0.000 と $0.192, \beta$ の平均值と 標準偏差は 0.000 と 0.234 となった。全データの推定䛊差 $\varepsilon$ の標準偏差 は0.320であったが， $\alpha$ と $\beta$ にり補正した推定誤差 $\varepsilon_{c}$ の標準偏差は 0.160 に減少した。一般的に地震動予測式の推定誤差は, 地震間と地 震内の推定誤差に分解され, 両者を比較すると地震内のばらつきが 大きいとされている例えば19)。本検討では， $\alpha$ は地震間の推定䛊差， $\beta$ と $\varepsilon_{c}$ は地震内の推定誤差に相当しており，整合的な結果となってい る。但し, $\beta$ は評価地点特有の不確実性であり, 認識論的不確実性と して整理できる。本検討では, $\beta$ に相当する空間的な推定誤差は予測 值の補正および空間補間で考慮される。よって, $\alpha$ と $\varepsilon_{c}$ のばらつきを 偶然的不確実性として取り扱うこととなる。両者を独立と仮定寸る と, 全体の推定残差の標準偏差は両者の二乗和平方根で表され

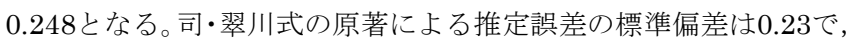
NIED検討の標準偏差は，振幅または断層最短距離の依存関係を採 用しているものの概ね 0.20 である。これらと比較すると，本検討は より大きなばらつきの採用となるが，対象地域の空間相関のモデル 化と合わせて地震動観測記録から得られたものであり，以降の検討 ではここを採用するものとする。
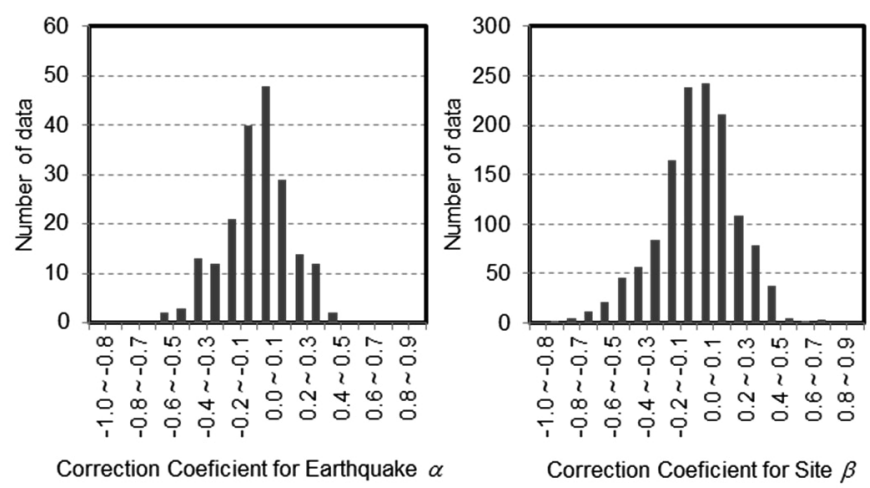

Fig.3 Correction coefficient for earthquake and site 


\section{4 地震動強度の空間的な相関のモデル化}

$2 つ の$ 観測地点を選択し, 同じ地震による 2 地点の観測記録の推定 残差 $\varepsilon_{c}$ の相関係数 $\rho$ を算出した。この相関係数 $\rho$ と $2 つ$ 観測地点の 離間距離 $(\mathrm{km})$ の関係をFig.4に示す。推定残差の相関係数は, 観測デ 一タの数が5つ以上のものを図示した。筆者ら 7 の検討と同様に 2 地 点間の距離が離れるにつれ, $\rho$ 㕕くばらつき, その平均が独立に近 くなる傾向が確認できる。ここでは, この傾向を筆者ら7) と同様に, 離間距離が $0 \mathrm{~km}$ で完全相関 $(\rho=1)$, 無限大で無相関 $(\rho=0)$ となるよ うな次式で表される近似モデルを設定しモデル化する。

$$
\rho=\exp \left(-\gamma \cdot z^{\delta}\right)
$$

ここで， $z$ は離間距離 $(\mathrm{km}), \quad \gamma$ と $\delta$ は関数の形状を規定する回帰定数 で, 相関係数の最小二乗誤差が最小になるように求める。回帰の結 果, $\gamma=0.044, \delta=1.043$ が得られた。Fig.4にはこの回帰曲線と林ら20) による回帰曲線を合わせて示した。林らの回帰曲線は本検討とは異 なる経験的距離減衰式と地震動データセットを採用した結果である が，ほぼ同様の結果となった。回帰曲線による相関係数は, 離間距 離が約 $20 \mathrm{~km}$ で 0.35 程度, 約 $40 \mathrm{~km}$ で 0.1 程度である。また, 約 $60 \mathrm{~km}$ になると0に近くなり，無相関に近くなる傾向となっている。筆者ら 7は, 地震動強度指標を最大加速度とした場合の回帰曲線も示して いるが，これも同様の結果となっており，経験的距離減衰式による 推定誤差の空間的な相関は，平均的にこのような傾向であるとみら れる。

\section{3. 地域空間の確率論的地震動ハザード評価}

\section{1 地域空間の確率論的ハザードの算定方法}

本検討は地域空間を対象とし, その周辺で発生する地震によって $t$ 年間に地震動強さ $y$ を超える地域の面積 $A$ （または, 所定区域に対す る面積割合）が $a$ を超える確率 $P(A>a ; t, y)$ を次式により算出する。

$$
P(A>a ; t, y)=1-\prod_{k}\left\{1-P_{k}(A>a ; t, y)\right\}
$$

ここで, $P_{k}(A>a ; t, y)$ は $k$ 番目の地震によって $t$ 年間に地震動強さ $y$

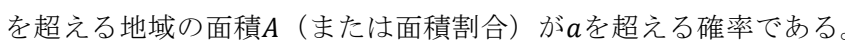

$k$ 番目の地震の発生確率を, 更新過程により非定常な地震活動を 表すモデルで仮定する場合， $P_{k}(A>a ; t, y)$ は次式で表される。

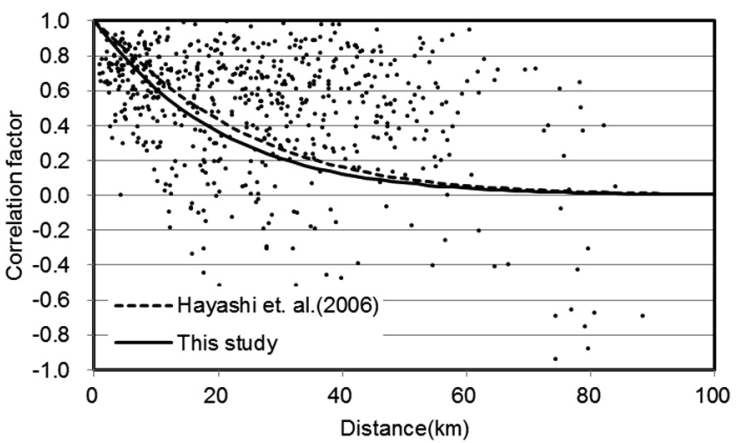

Fig.4 Relationship between correlation factor and separation distance

$$
P_{k}(A>a ; t, y)=P\left(E_{k} ; t\right) P\left(A>a ; y \mid E_{k}\right)
$$

ここで, $P\left(E_{k} ; t\right)$ は $t$ 年間における $k$ 番目の地震の発生確率, $P(A>$ $\left.a ; y \mid E_{k}\right)$ は地震 $k$ が発生した場合に, 地震動強さ $y$ を超える地域の面 積 $A$ （または面積割合）が $a$ を超える条件付き確率である。

一方, $k$ 番目の地震の発生を定常ポアソン過程でモデル化する場 合は, $P_{k}(A>a ; t, y)$ は次式で表される。

$$
P_{k}(A>a ; t, y)=1-\exp \left\{-v\left(E_{k}\right) P\left(A>a: y \mid E_{k}\right) \cdot t\right\}
$$

ただし, $v\left(E_{k}\right)$ は $k$ 番目の地震の年あたりの発生頻度である。 以降では，(7)式を超過面積ハザードと呼ぶ。これを確率や面積に ついて連続的に求めると超過面積八ザードカーブとして表せる。（8） (9)式中の $P\left(A>a ; y \mid E_{k}\right)$ の算出方法を次節に示寸。

\section{2 地震動強度の空間相関モデルの SPSHA への適用}

$P\left(A>a ; y \mid E_{k}\right)$ は，モンテカルロシミュレーション（以下，MCS と記す）を用いて算出する。この時，一つの地震動分布サンプルの 生成は地震動強度の空間相関を考慮し, 以下の手順で行う。

地震発生時にある地域空間内の複数の観測地点で記録が得られて いる場合, Simple Kriging 法を用いて地震動の空間分布を推定する 手法が提案されている。過去の被害地震でも震動強度分布が推定さ れた実績がある 21)。Simple Kriging 法による地震動の空間分布推定 では, 複数地点の地震動強度の平均値（トレンド成分）と共分散を 既知として，任意の地点の地震動強度を空間的に補間する。ここで は，この手法を評価対象地域の工学的基盤での PGV の予測に適用 する。地震動強度の平均值は, 2 章で示した地震動予測手法で算出 される工学的基盤面における $P G V_{b 400}$ とする。共分散は観測記録の分 析に基づく。 $N$ 地点の地震観測点で工学的基盤における地震動強度 の観測值 $W\left(x_{i}\right)(i=1 \sim N)$ が与えられた場合, 任意の地点 $r$ の地震動 強度の推定値 $x_{r}$ は以下の式で表される。

$$
\log \left(x_{r}\right)=\log \left(\hat{x}_{r}\right)+\sum_{i=1}^{N} \lambda_{i}\left(\log \left(x_{i}\right)-\log \left(\widehat{x}_{l}\right)\right)
$$

ここで, $\hat{x}$ は地震動強度の平均值で工学的基盤における $P G V_{b 400}$ であ る。添え字 $r$ は地点を表す。重夕係数 $\lambda_{i}(i=1 \sim N)$ は, 推定誤差分散の 最小化を図り，次の連立方程式の解として求められる。

$$
\sum_{j=1}^{N} \lambda_{j} \cdot C\left(W\left(x_{i}\right), W\left(x_{j}\right)\right)=C\left(W\left(x_{i}\right), W\left(x_{r}\right)\right) \quad(i=1 \sim N)
$$

ここで, $C\left(W\left(x_{i}\right), W\left(x_{j}\right)\right)$ は $i$ 地点と $j$ 地点の観測值の共分散である。 地震動強度の空間相関を考慮した SPSHA では，(10)式右辺の観測 值 $x_{i}$ を MCS により以下の式を用いて疑似的に生成する。

$$
\log \left(x_{i}\right)=\hat{x}_{i}+\beta_{i}+\varepsilon_{e}\left(0, \sigma_{e}\right)+\varepsilon_{c}\left(0, \sigma_{c}\right)
$$

ここで， $x_{i}$ はサンプル地震動強度值， $\hat{x}$ は(5)式の右辺により算出 される地震動強度の対数中央值, $\varepsilon_{e}\left(0, \sigma_{e}\right)$ は平均 0 , 標準偏差が $\sigma_{e}$ の 
ランダム変数, $\varepsilon_{c}\left(0, \sigma_{o}\right)$ は平均 0 , 標準偏差が $\sigma_{c}$ のランダム変数であ る。 $\sigma_{e}$ は地震間のばらつきを示し, 地震補正係数 $\alpha$ の標準偏差とする。 また, $\varepsilon_{e}$ は全観測地点において共通で完全相関を仮定する。 $\sigma_{c}$ は地 震内のばらつきの大きさを示し, (1),(2)式で示寸推定残差 $\varepsilon_{c}$ の標準 偏差とする。また, $\varepsilon_{c}$ の乱数生成に際しては, 2.4 節のデータセット の分析から得られた観測地点間の空間的な相関を与える。なお, 観 測点ペアで十分なデータ数がない観測点（ここではデータ数を 4 以 下とした)については(6)式の指数関数型のモデル式から離間距離に 応じて相関係数を設定する。以上より, 地震動強度の空間相関を考 慮した評価対象地域の地震動分布の推定は, 以下の手順で行う。

手順 1 : 観測記録の分析を行い, 補間対象とする $n$ 個の評価地点にお いて(11)式の入を求める。

手順 $2:$ 観測地点間の相関行列 $R$ を作成する。 $R$ は $N$ 行 $N$ 列で, その要 素 $\rho_{i j}$ は観測地点 $i$ と $j$ 観測記録から求める。但し, 観測記録 が存在しない場合やデータ数が十分でない場合には, 両観測 地点の離間距離を用いて(6)式を用いて算出する。

手順 3 : 相関行列 $R$ から分散共分散行列を作成する。相関係数が観測 記録に基づく場合は分散や共分散も同様に観測記録に基づ く值を採用する。そうでない場合は, 地震内の推定誤差の標 準偏差を用いて分散や共分散を算出する。

手順 4 : 分散共分散行列を用いて, 観測地点 $N$ 個について相関を有す る正規乱数 $\varepsilon_{c}$ を生成する。

手順 5 : 地震間の推定誤差の標準偏差を用いて正規乱数 $\varepsilon_{e}$ を生成する。 手順 6 : 観測地点 $i$ における工学的基盤の $P G V_{b 400}$ の対数中央值を算出 する。これに手順 4,5 で生成した乱数と地点補正係数 $\beta_{i}$ を考 慮して地震動サンプルを生成する（(12)式）。この計算を $N$ 個の観測地点について繰り返す。

手順 7 : 生成した $N$ 個の観測地点の地震動サンプルを用いて, $n$ 個の 評価地点の工学的基盤の $P G V_{b 400}$ を(10)式により推定する。

手順8 : 全評価地点の $P G V_{b 400}$ に地盤増幅率を乗じて地表面の地震動 $P G V_{s}$ を求める。地盤増幅率は, 2.2 節と同様である。

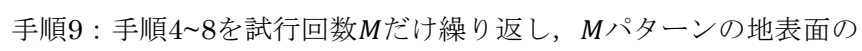
地震動分布サンプルを得る。これから, 地震動強さ $y$ を超え る地域の面積 $A$ が $a$ を超える条件を満たす地震動分布サンプ ルを抽出し, $P\left(A>a ; y \mid E_{k}\right)$ を得る。

後述の試算では, 条件設定及び結果表示における地震動強度指標 として地表面における計測震度を採用する。この時は, 上記の手順 8 と 9 の間で, 地表面の $P G V_{S}$ を計測震度に変換する。地表面における 計測震度は, NIED検討を参照し, 翠川ら 22) と藤本・翠川(2005) 23)が 提案する次の関係式により, 地震タイプごとに計測震度 $I$ を算出する。

(プレート境界・プレート内地震)

$$
I=2.68+1.72 \log P G V_{S}
$$

\section{(内陸地殼内地震)}

$$
I=2.002+2.603 \log P G V_{s}-0.213\left(\log P G V_{s}\right)^{2}
$$

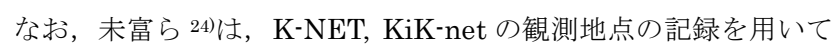

Simple Kriging 法により地震動を空間補間する場合, 観測点の影響 範囲を決める相関距離として $20 \mathrm{~km}$ 程度が妥当としている。よって, 後述の適用試算 (4.2 節) では評価対象地点より $20 \mathrm{~km}$ 以内の観測 点の記録を用いて補間を行うこととする。Fig.4 によれば離間距離 が $20 \mathrm{~km}$ 以上では推定残差の相関係数はほぼ 0.35 以下となり相関 が非常に弱くなっており，これと整合的であると考える。

以上より, Simple Kriging 法と MCS を組み合わせる事で, 基準 点（ここでは地震観測地点とした）の地震動をサンプリングし，そ の他の地点は空間補間することで, 空間的な相関を考慮して全地点 の地震動を推定することが可能となる。また, 全評価地点について 相関を考慮したサンプリングを行わずに済むため, 計算量を減らす 事が可能となる。加えて, 本手法では観測記録から得られた地点補 正や空間的な相関関係を考慮できるため, 地域の地震観測から得ら れる特性を反映した地震動ハザード評価であるといえる。

\section{4. モデル地域への適用試算}

神奈川県を対象に SPSHA を実施する。神奈川県は, 相模卜ラフ に極めて近くフィリピン海プレートの沈み込みに伴う地震の影響を 受ける。また, 西方の南海トラフ沿いで発生する大地震について県 の西方エリアを中心に強震動が発生することが予想される。内陸部 には複数の活断層が存在しており, 三浦半島断層群や塩沢断層帯は 発生確率が高い。確率論的地震動予測地図 5)でも, このような多様 な地震の影響により全国的に地震リスクの高い地域である。

\section{1 本手法の検証}

本手法では, 地域の超過面積ハザードを算出する際に地震動強度 の空間補間を行う。本節では, シナリオ地震を対象とした検討によ り本手法の妥当性検証や課題確認を行う。対象地域は, Fig. 5 に示寸 伊勢原断層帯を含む $30 \times 30 \mathrm{~km}$ の矩形領域とする。地震シナリオは, 伊勢原断層帯による地震（Mw6.6）とし，全メッシュについて空間 相関を考慮して算出する方法（ケース 1）と，提案手法により算出 する方法（ケース 2) の両者で評価を行い, 超過面積八ザードを比 較する。提案手法による計算では, 対象地域内外に複数の基準点を 必要とする。ここでは検証用として, 対象地域を中心に含む $50 \times$ $50 \mathrm{~km}$ の領域に基準点を $5 \mathrm{~km}$ 間隔に配置する。Simple Kriging 法 で用いる相関距離は $10 \mathrm{~km}$ (ケース $2 \mathrm{~A}), 20 \mathrm{~km}$ （ケース $2 \mathrm{~B}$ ) の 2 ケースとする。ここでは検証のため, 地点補正係数 $\beta$ は考慮しない。

MCS の試行回数は 1,000 回とする。超過面積ハザードを, Fig.6に 示す。地震動強度は, 震度 7 , 震度 6 強以上, 震度 6 弱以上, 震度 5 強以上, 震度 5 弱以上（同図および以降の図では, それぞれ 7,6+, 6-,5+,5-と記す) とした。また, 各震度の超過面積八ザードの平 均と標準偏差を Table 1 に示す。いずれも面積は, 評価対象地域の総 面積に対する割合とした。Fig.6 の縦軸は地震が発生した場合の条 件付き超過確率となり, 対象とする震度が大きくなると事象の超過 確率が小さくなる関係となる。また, 与えられた震度の面積率が大 きくなると超過確率は小さくなる。各ケースを比較すると, ケース $2 \mathrm{~A}$ は概ねケース 1 と整合的な結果となった。ケース $2 \mathrm{~B}$ は, 相関距 離が長く, 地震動推定のための基準点を多く採用して地震動を推定 する。そのため, 地域として地震動強度分布が平滑化され, 超過面 積ハザードの標準偏差が大きくなる傾向となる。このように震源近 
傍で地震動が極めて大きく, 対象地域内で地震動のコントラストが 大きい時は，相関距離によって合致性が悪くなる場合がある。以上 より，本手法による評価は妥当であるが，評価対象地域と震源との 位置関係によっては, 基準点となる観測点の配置によって精度が劣 る場合がある点が確認された。

\section{2 モデル地域における試算}

(1) 評価条件

モデル地域は神奈川県とする。神奈川県の境界位置と地震動強度 の推定に用いる基準点（地震観測点）の配置を考えて, Fig.7の矩形

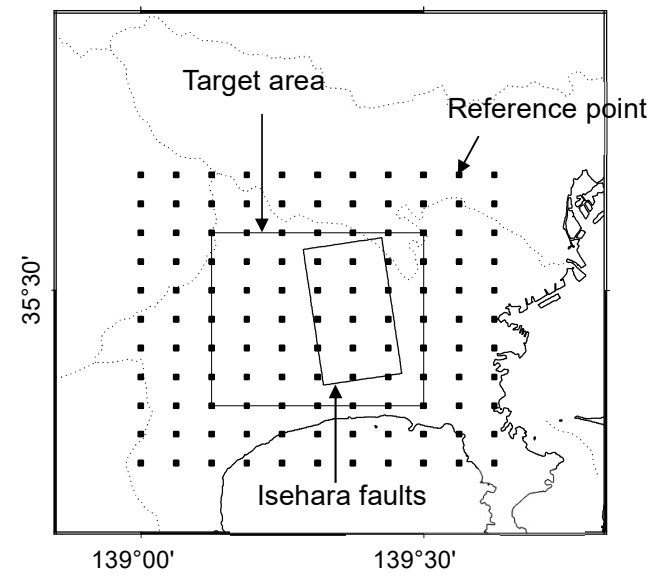

Fig.5 Target area for verification test

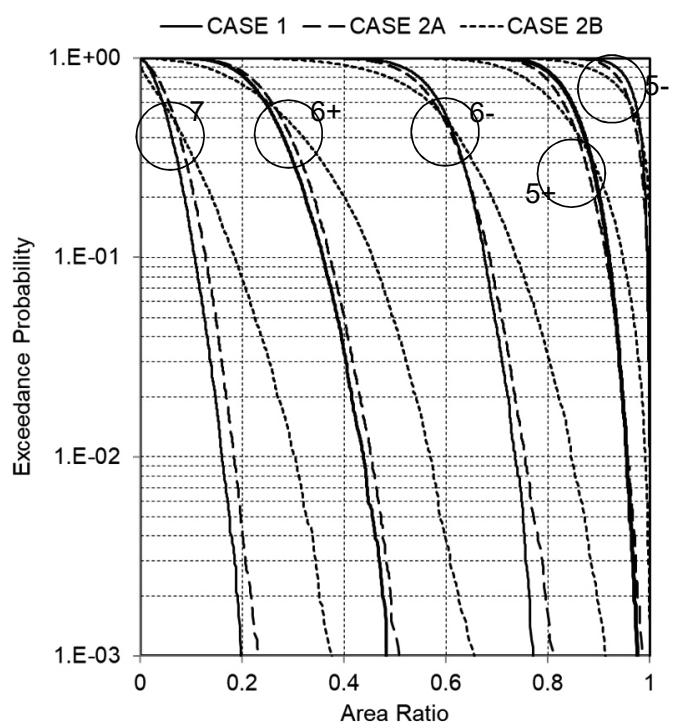

Fig.6 Verification: Area ratio hazard curve

Table1 Verification: Probabilistic characteristics of area ratio

\begin{tabular}{ccccccc}
\hline \multirow{2}{*}{ CASE } & \multicolumn{5}{c}{ Lower bound of JMA seismic intensity } \\
\cline { 2 - 7 } & & $5-$ & $5+$ & $6-$ & $6+$ & 7 \\
\hline \multirow{2}{*}{1} & Mean & 0.971 & 0.857 & 0.599 & 0.266 & 0.059 \\
\cline { 2 - 7 } & SD & 0.025 & 0.050 & 0.063 & 0.070 & 0.036 \\
\hline \multirow{2}{*}{$2 \mathrm{~A}$} & Mean & 0.962 & 0.843 & 0.593 & 0.279 & 0.071 \\
\cline { 2 - 7 } & SD & 0.031 & 0.056 & 0.073 & 0.072 & 0.042 \\
\hline \multirow{2}{*}{$2 \mathrm{~B}$} & Mean & 0.954 & 0.832 & 0.589 & 0.289 & 0.081 \\
\cline { 2 - 7 } & SD & 0.052 & 0.091 & 0.122 & 0.124 & 0.073 \\
\hline
\end{tabular}

領域を評価対象領域とする。評価対象領域の内部は約 $1 \mathrm{~km}$ 平方のメ ッシュ（標準地域メッシュ : 第3次メッシュ）に離散化し, メッシュ の中心地点における工学的基盤の地震動を推定する。地表の地震動 の算出は, 約 $250 \mathrm{~m}$ 平方のメッシュ (4分の 1 地域メッシュ) において 地盤増幅率を用いて算出する。地盤増幅率は藤本・翠川(2006) 17)に より算出したデータが地震八ザードステーション25)から公開されて おり,これを用いる。評価対象領域内の $1 \mathrm{~km}$ メッシュ数は $5,231 て ゙$, 地震観測地点の数は 83 である。神奈川県の総面積に対する所与の震

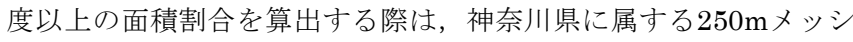

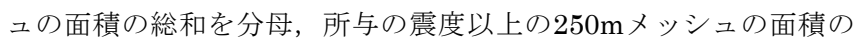
総和を分子とする。震源モデルについても, NIED検討と同様とし, 地震八ザードステーション25)から取得した。地震の発生確率は, 今 後30年間における地震発生確率であり, 一部の地震は更新過程（起 点日：2018年1月1日）を採用している。MCSによる地震動分布サン プルの生成においては, 2 章の検討に基づき, 地震間の推定誤差の標 準偏差を 0.192 , 地震内の推定誤差の標準偏差を 0.16 とする。MCS の計算試行回数は1,000回とする。また, 観測地点の地震動の推定に おいては地点補正係数 $\beta$ を考慮する。

\section{(2) 評価結果}

神奈川県の領域を対象に算出された超過面積ハザードカーブを Fig.8に示す。超過面積八ザードカーブの縦軸は今後 30 年以内にその 事象が発生する超過確率を, 横軸は神奈川県の総面積に対する面積 割合を示している。所与の震度が与えられたとき，超過面積八ザー ドカーブより，その震度を超える面積の割合の超過確率を読み取る ことができる。例えば, Table2に示すように, 神奈川県において震 度 5 弱以上の面積が $10 \%$ 以上となような地震は今後 30 年以内に 100\%であり，ほぼ確実に発生するような確率であることが分かる。 また, 面積の $90 \%$ 以上が震度 5 弱以上となる確率は $56.8 \%$ となり, 発 生する可能性が非常に高い事がわかる。建物等の構造物に被害が発 生する可能性が高い震度 6 弱以上をみると, 県内面積の $10 \%$ 以上で発 生する確率は $79.2 \%$ であが，面積割合が大きくなるにつれて低下 し，75\%以上の面積割合では $2.5 \%$ 程度となる。甚大な被害を及ぼす 震度 7 は, 面積割合が $10 \%$ 以は $1.6 \%$ （再現期間:1860年相当の確率 值）で，25\%以上では $0.1 \%$ （再現期間:約 3 万年相当の確率値）に低

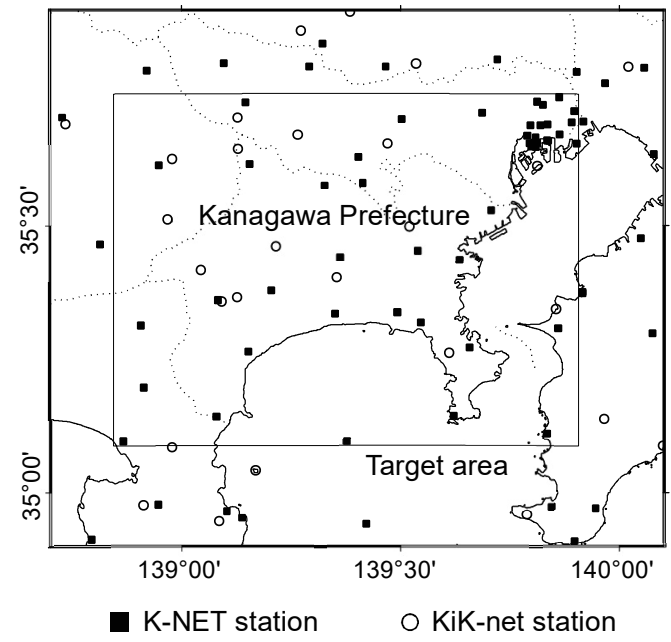

Fig.7 Target area 


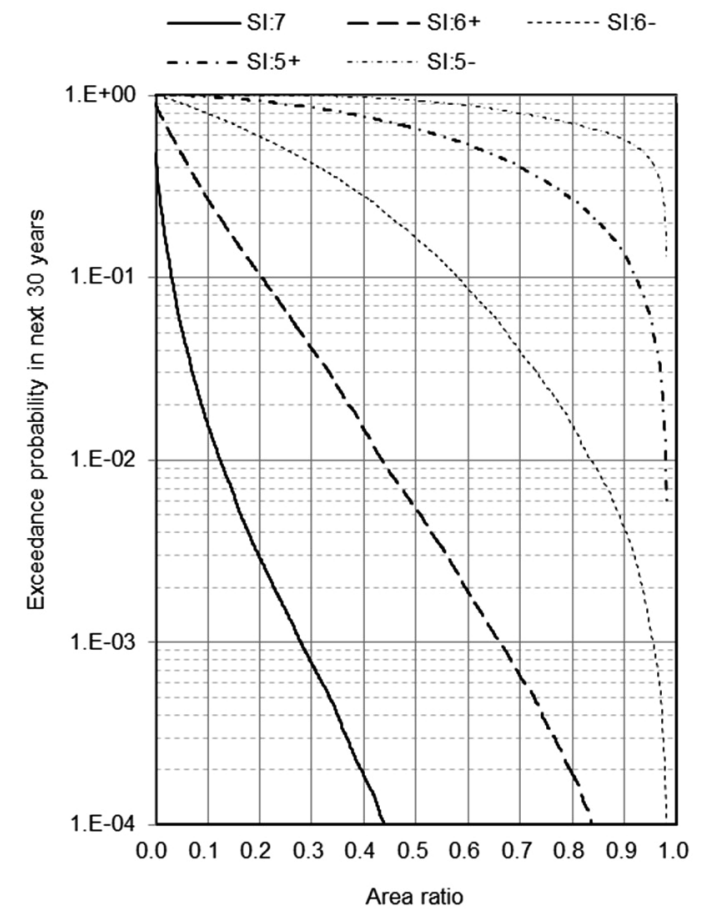

Fig.8 Area ratio hazard curve for Kanagawa Pref.

下寸る。次に, 所与の超過確率を与えたとき対応する各震度の面積 をTable3に示す。今後 30 年における超過確率 $6 \%$ は, 再現期間で約 485 年程度の確率值に相当し, この時, 震度 6 弱以上のエリアは約 $65 \%$, 震度 7 の領域は約 $5 \%$ と, 非常に広域が強震動となる可能性が 高いことが分かる。このような表現方法は地域空間における地震動 の面積 (または総面積に対する割合) と超過確率の関係を明確にし, 地域内の地震動ハザードの広域性を確率的に理解できる。

\section{（3）地震動強度の空間相関について}

地震動強度の空間相関を考慮すると, 近隣地域の地震動の確率特 性が適切に処理できる。前述の結果では, この点が不明瞭なので, Fig.9にサンプリングした地震動分布の例題を示す。同図には三浦半 島断層群（主部：武山断層）の地震について, 地震動予測式による 平均 (Case0), 提案手法 (Case1), 地震動のばらつきを各地点で 独立とした場合（Case2）, 地震動のばらつきを各地点で完全相関 とした場合（Case3）の地震動分布サンプルを示した。Case2では, 地震間のばらつきを完全相関, 地震内のばらつき（ここでは(12)式 の $\beta$ と $\varepsilon_{c}$ の誤差) を独立とした。Case3では, 地震間と地震内のばら つきをそれぞれ完全相関とした。なお, Case 2,3では空間補間を用い ずに算出した。平均的な地震動分布に対して, 地震動の空間相関を 独立と取り扱うと同図（Case2）に示すようにモザイク状の不自然 な地震動分布となる。また, 空間相関を完全相関とするとCase3の ようにCase1の地震動分布を全地域で線形的に増加させた分布とな る。よってCase2,3では, 県内の小さな領域を対象として超過面積八 ザードを算出すると過少または過大な評価となり得る。Case1は, 空間相関を適切に反映しているため, 平均的な分布に対して地震動 が強い小地域や弱い小地域が含まれ, より自然な分布となる。確率 的に被害評価を行う場合には, 隣接する地域の地震動強度の相関が 結果に大きな影響があるため, 空間相関の考慮が必要となる。

\section{5. 地震防災への適用}

前章結果の地震防災の活用方法として，3つの事例を検討した。

\section{1 地域に影響を及ぼす地震の把握}

前章の結果を用いて神奈川県の超過面積ハザードに対して影響を 及ぼす地震の把握を行う。ある地点を対象とする場合は, NIED検 討のように, 地震動ハザードカーブに対して各地震の貢献度を求め ることで，影響の高い地震を定量的に把握することができる。これ を, 本提案手法に適用すると超過面積ハザードに対する各地震の影 響を定量的に把握できる。ここでは, NIED検討と同様に超過面積

Table2 Exceedance probability in next 30 years corresponding to the area ratio for seismic intensity

\begin{tabular}{cccccc}
\hline \multirow{2}{*}{ Area ratio } & \multicolumn{5}{c}{ Lower bound of JMA seismic intensity } \\
\cline { 2 - 6 } & $5-$ & $5+$ & $6-$ & $6+$ & 7 \\
\hline $10 \%$ & $100.0 \%$ & $98.1 \%$ & $79.2 \%$ & $27.0 \%$ & $1.6 \%$ \\
\hline $25 \%$ & $99.5 \%$ & $89.4 \%$ & $50.5 \%$ & $6.6 \%$ & $0.1 \%$ \\
\hline $50 \%$ & $93.6 \%$ & $65.4 \%$ & $16.3 \%$ & $0.5 \%$ & $0.0 \%$ \\
\hline $75 \%$ & $74.7 \%$ & $33.5 \%$ & $2.5 \%$ & $0.0 \%$ & $0.0 \%$ \\
\hline $90 \%$ & $56.8 \%$ & $13.4 \%$ & $0.4 \%$ & $0.0 \%$ & $0.0 \%$ \\
\hline
\end{tabular}

Table3 Area ratio corresponding to a given exceedance probability in next 30 years for seismic intensity

\begin{tabular}{cccccc}
\hline \multirow{2}{*}{ EP30 } & \multicolumn{5}{c}{ Lower bound of JMA seismic intensity } \\
\cline { 2 - 6 } & $5-$ & $5+$ & $6-$ & $6+$ & 7 \\
\hline $1 \%$ & $98.1 \%$ & $97.9 \%$ & $83.5 \%$ & $43.4 \%$ & $12.4 \%$ \\
\hline $3 \%$ & $98.1 \%$ & $96.9 \%$ & $73.2 \%$ & $33.4 \%$ & $7.1 \%$ \\
\hline $6 \%$ & $98.1 \%$ & $94.9 \%$ & $65.2 \%$ & $26.0 \%$ & $4.6 \%$ \\
\hline $14 \%$ & $98.0 \%$ & $89.6 \%$ & $52.8 \%$ & $16.8 \%$ & $2.3 \%$ \\
\hline $26 \%$ & $97.5 \%$ & $80.6 \%$ & $41.6 \%$ & $10.4 \%$ & $0.9 \%$ \\
\hline
\end{tabular}

EP30: Exceedance probability in next 30 years

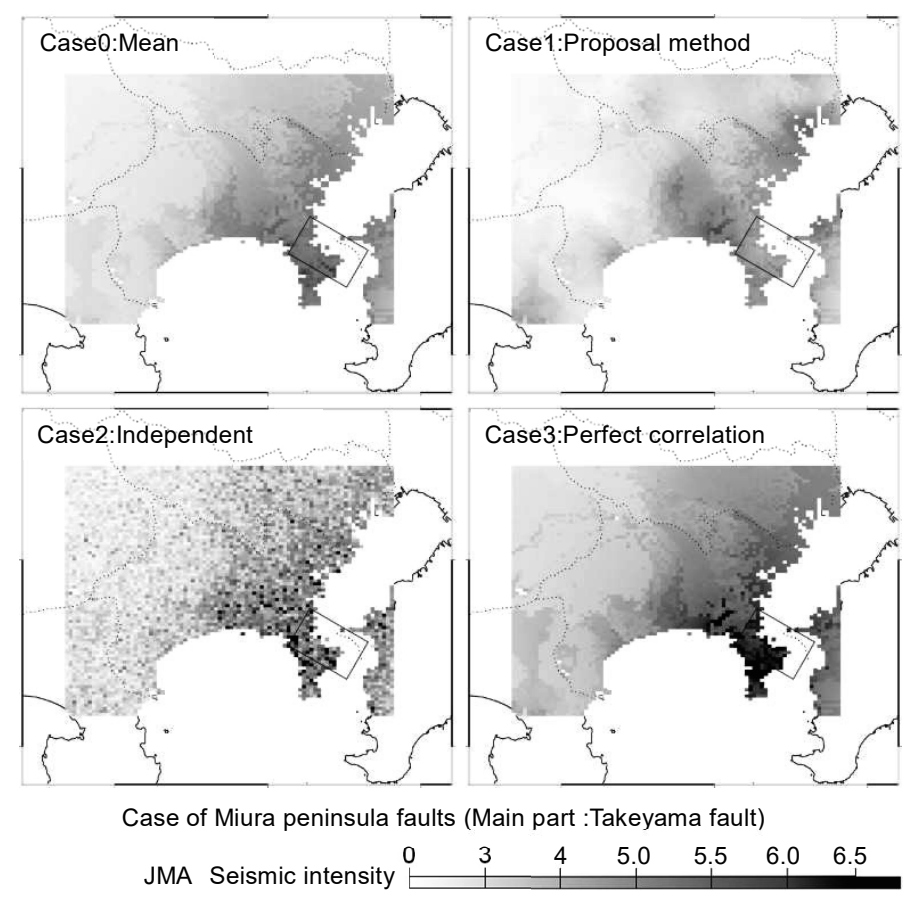

Fig.9 Examples of sampling of ground motion distribution 
八ザードカーブを 3 つの地震カテゴリー（ I ：震源を特定できる海 溝型の地震, II : 震源を特定しにくい海溝型の地震, III : 活断層な ど陸域と海域の浅い地震）に分解し, 各カテゴリーの貢献度を算出 した。震度 5 弱以上, 震度 6 弱以上, 震度 7 の超過面積八ザードに 対する各地震カテゴリーの貢献度を Fig. 10 に示す。神奈川県に多大 な影響を及ぼす南海トラフと相模トラフ周辺で発生する大地震はカ テゴリーI に分類される。どの震度においてもカテゴリーI の貢献 度は, 面積率が大きくなるにつれて増加し, 広域な地震動八ザード に対して支配的であることが分かる。カテゴリーIIには，相模トラ フ周辺の M7 クラスの地震が含まれており, 神奈川県下で発生寸る 場合も多いことから，狭域から広域まで一定程度の貢献度がある。 カテゴリーIIIの地震は, 他のカテゴリーの地震に比して発生確率が 低く, どの震度のケースにおいても相対的に影響度が小さい。カテ ゴリーIIIの震度 7 は, 最も広域のケースでも面積率 0.15 程度であ ることが分かる。震度 7 のような強震動を考えた場合, 地震動が広 域になるほど, 貢献度はカテゴリー I が支配的になる。このような 分析を通して, 地域空間の強震動の広域性の観点において影響度の 高い地震を確認し, 地震被害想定で設定すべき地震像の判断に用い ることができる。

\section{2 決定論的な想定地震の地震動ハザード評価結果との比較}

神奈川県が実施した地震被害想定 ${ }^{26)}$ (以下, 神奈川県想定と記す) では，神奈川県に及ぼす被害の大きさ・地域的分布や，地震発生の 切迫度を考慮して 11 の想定地震を選定している。これらの想定地 震は最終的に「対策検討のための被害シナリオを作成する地震」と, 被害だけを把握し「参考的位置づけとする地震」に分けられる。こ の内, 8 地震について統計的グリーン関数法により地震動八ザード が決定論的に評価されている。しかし, この地震動ハザードの評価 結果は, 震源パラメータの設定などにより大きく結果が変わり得る。 多様に評価できる地震動強度分布の中で, 最終的に採用されたケー スの位置づけを確認することが重要と考える。そこで, これらの地 震シナリオについて, 被害の発生の可能性が高い震度 6 弱以上, 6 強以上, 震度 7 について, 神奈川県の想定シナリオにおける震度の 面積率を算出し, その確率特性を確認する。神奈川県想定と本検討 の震源モデルで概数震源が一致する三浦半島断層群の地震, 大正関 東地震, 南海トラフ巨大地震の 3 シナリオについて, 本手法に基づ く超過面積の確率特性と, 神奈川県想定による面積割合を比較した 結果を Table4 に示す。三浦半島断層群の地震では, 本検討より求め た震度 6 弱以上の面積率は, 平均が 0.3 , 標準偏差が 0.11 である。 一方, 神奈川県想定では震度 6 弱以上の面積割合は 0.22 となって おり, $25.8 \%$ ile に相当する。このパーセンタイルは $50 \%$ が平均的で, $50 \%$ 未満では平均より小さな地震動ハザードを， $50 \%$ 超ではより大 きな地震動八ザードを想定していることとなる。三浦半島断層群の 震度 6 強以上でも $22.4 \%$ ile と平均より小さな想定となっているこ とが分かる。一方, 大正型関東地震では, いずれの震度も $50 \%$ を超 えており, 大きな地震動ハザードを採用している。南海トラフ地震 では, 本手法の結果は, どの震度の場合も神奈川県想定に比して非 常に大きくなっている。本検討では, 南海トラフ震源域との断層最 短距離を用いて経験的距離減衰式により地震動を算出している。一 方, 神奈川県想定が採用する統計的グリーン関数法では, 強震動生
成域が遠方に配置されており，微視的な震源パラメータの設定が大 きく影響し, 結果としてより小さな地震動となっているためと考え られる。これは広い震源域を持つ大規模地震の地震動を断層最短距 離による経験的距離減衰式で評価する上での課題と捉えられる。巨 大地震への適用性については課題が確認されるものの, 設定した地 震シナリオの八ザードの確率特性を把握できることは，地震被害想 定において決定的に評価される地震動ハザードの妥当性の議論に役 立つものと考える。

\section{3 想定地震の超過面積ハザードの生起確率について}

本節では超過面積八ザードカーブに基づき，シナリオ地震につい て想定された地震動ハザードの確率を確認する。神奈川県想定によ る 8 つの想定地震の地震動ハザードについて, 各地震動強度の面積 （神奈川県全体面積に対する面積率で記す）と超過面積ハザードカ ーブに基づくその事象の発生確率を算出する。結果を Table5 に示 す。神奈川県想定では, 内閣府中央防災会議が想定している都心南 部直下地震（The southern Tokyo inland earthquake）が発生する と, 全体面積の約 $56 \%$ の割合で震度 6 弱以上となる。このような地 震動分布に相当する地震動ハザードが発生する確率は超過面積八ザ ードカーブから今後 30 年以内に $11.7 \%$ であることが分かる。また, この地域で発生する最大規模の地震である相模トラフ沿いの最大ク ラスの地震 (Probable maximum earthquake around Sagami trough) は, 神奈川県想定で震度 6 弱以上となる面積の割合が約 $94 \%$ となっているが,このような地震動八ザードの発生確率は $0.2 \%$ 全 シナリオの中で最も低い確率となっている。なお，この地震は神奈 川県想定でも参考地震と位置付けられている。大正型関東地震と元 禄型関東地震は，ほぼ同様の地震動で，両者とも震度 6 弱以上の面 積率は約 $89 \%$ と非常に広域であり, 30 年以内の発生確率は $0.5 \%$ と なる。神奈川県想定では, 大正型関東地震は被害シナリオを設定す る地震, 元禄型関東地震は長期的に対応する参考的な位置づけと定 められている。よって, 震度 6 弱以上の超過面積割合について 30 年 以内に発生確率 $0.5 \%$ （再現期間にして約 5,985 年に相当）が計画を 検討する地震と参考的位置づけの閾值であるとの見方ができる。こ のような地震動八ザードは, 県内全域で被害が甚大となる広域災害

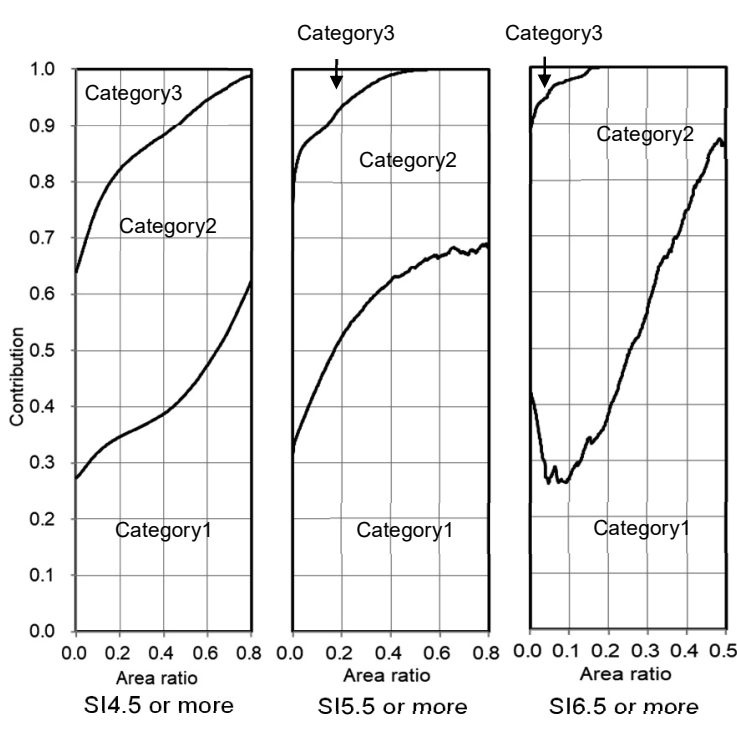

Fig.10 Contribution of earthquake type 
Table4 Area ratio of earthquake hazard scenarios in the Kanagawa earthquake damage assessment and probabilistic characteristics

\begin{tabular}{|c|c|c|c|c|c|}
\hline \multirow{2}{*}{$\begin{array}{c}\text { Earthquake } \\
\text { scenario }\end{array}$} & \multirow{2}{*}{ M } & \multicolumn{4}{|c|}{ Lower bound of seismic intensity } \\
\hline & & & $6-$ & $6+$ & 7 \\
\hline \multirow{4}{*}{$\begin{array}{l}\text { Miura peninsula } \\
\text { faults }\end{array}$} & \multirow{4}{*}{7.0} & MEAN & 0.30 & 0.12 & 0.02 \\
\hline & & SD & 0.11 & 0.09 & 0.04 \\
\hline & & AR & 0.22 & 0.03 & - \\
\hline & & $\mathrm{PC}$ & $25.8 \%$ & $22.4 \%$ & - \\
\hline \multirow{4}{*}{$\begin{array}{c}\text { Taisho Kanto type } \\
\text { earthquake }\end{array}$} & \multirow{4}{*}{8.2} & MEAN & 0.77 & 0.41 & 0.12 \\
\hline & & SD & 0.17 & 0.20 & 0.11 \\
\hline & & AR & 0.89 & 0.62 & 0.14 \\
\hline & & $\mathrm{PC}$ & $69.9 \%$ & $83.1 \%$ & $68.8 \%$ \\
\hline \multirow{4}{*}{$\begin{array}{l}\text { Probable maximum } \\
\text { earthquake around } \\
\text { Nankai trough }\end{array}$} & \multirow{4}{*}{9.0} & MEAN & 0.34 & 0.08 & 0.01 \\
\hline & & SD & 0.19 & 0.09 & 0.02 \\
\hline & & AR & 0.01 & 0.00 & 0.00 \\
\hline & & $\mathrm{PC}$ & $0.3 \%$ & $0.1 \%$ & $0.1 \%$ \\
\hline
\end{tabular}

MEAN: Mean of area ratio by proposal method

SD: Standard deviation of area ratio by proposal method

AR: Area ratio of each scenario in earthquake damage assessment

PC: Percentile of conditional probability when the earthquake occurs.

Table5 Area ratio corresponding to a given exceedance probability in next 30 years for seismic intensity

\begin{tabular}{|c|c|c|c|c|c|}
\hline \multirow{2}{*}{ Earthquake scenario } & \multirow{2}{*}{ M } & \multicolumn{4}{|c|}{ Lower bound of seismic intensity } \\
\hline & & & $6-$ & $6+$ & 7 \\
\hline \multirow{2}{*}{$\begin{array}{l}\text { The southern Tokyo } \\
\text { inland earthquake }\end{array}$} & \multirow{2}{*}{7.3} & AR & 0.56 & 0.10 & 0.00 \\
\hline & & EP30 & $11.7 \%$ & $25.5 \%$ & - \\
\hline \multirow{2}{*}{$\begin{array}{l}\text { Miura peninsula } \\
\text { faults }\end{array}$} & \multirow{2}{*}{7.0} & AR & 0.22 & 0.03 & 0.00 \\
\hline & & EP30 & $55.2 \%$ & $57.0 \%$ & - \\
\hline \multirow{2}{*}{$\begin{array}{c}\text { The western } \\
\text { Kanagawa } \\
\text { earthquake }\end{array}$} & \multirow{2}{*}{6.7} & AR & 0.10 & 0.01 & 0.00 \\
\hline & & EP30 & $80.0 \%$ & $81.6 \%$ & - \\
\hline \multirow{2}{*}{ Tokai earthquake } & \multirow{2}{*}{8.0} & AR & 0.00 & 0.00 & 0.00 \\
\hline & & EP30 & $99.5 \%$ & $87.9 \%$ & - \\
\hline \multirow{2}{*}{$\begin{array}{c}\text { Taisho Kanto type } \\
\text { earthquake }\end{array}$} & \multirow{2}{*}{8.2} & AR & 0.89 & 0.62 & 0.14 \\
\hline & & EP30 & $0.5 \%$ & $0.1 \%$ & $0.8 \%$ \\
\hline \multirow{2}{*}{$\begin{array}{l}\text { Genroku Kanto type } \\
\text { earthquake }\end{array}$} & \multirow{2}{*}{8.5} & AR & 0.89 & 0.62 & 0.14 \\
\hline & & EP30 & $0.5 \%$ & $0.1 \%$ & $0.8 \%$ \\
\hline \multirow{2}{*}{$\begin{array}{l}\text { Probable maximum } \\
\text { earthquake around } \\
\text { Sagami trough }\end{array}$} & \multirow{2}{*}{8.7} & AR & 0.94 & 0.75 & 0.32 \\
\hline & & EP30 & $0.2 \%$ & $0.0 \%$ & $0.1 \%$ \\
\hline \multirow{2}{*}{$\begin{array}{l}\text { Probable maximum } \\
\text { earthquake around } \\
\text { Nankai trough }\end{array}$} & \multirow{2}{*}{9.0} & AR & 0.01 & 0.00 & 0.00 \\
\hline & & EP30 & $98.3 \%$ & $87.9 \%$ & $42.6 \%$ \\
\hline
\end{tabular}

$A R$ : Area ratio of each scenario in earthquake damage assessment EP30: Exceedance probability in next 30 years

のケースであり, 極めて確率も小さいことから, この程度の確率に 相当する地震（および地震動八ザード）を最大クラスの地震（およ び地震動ハザード）として設定することも議論によって可能と考え る。最大クラスの地震について確率を考慮して議論して設定する場 合, その地震の発生確率だけでは不十分で, 様々な地震による地震 動ハザードの生起確率を踏まえての議論が重要と考える。

\section{6. まとめ}

本研究では, 地震動強度の空間相関と地震動予測の補正を考慮し
た地域空間の確率論的地震動ハザード評価手法を提案し，その結果 を超過面積ハザードカーブとして示した。本手法は，地震観測地点 の位置における地震動強度の MCS サンプリングと Simple Kriging による地震動の空間補間を組み合わせたものである。これらの手法 により地震動強度の空間相関を確率的に考慮することが可能となる。 また，モデル地域について試算を行い，地域防災への適用方策につ いて検討した。以上の検討から以下の結果が得られた。

1）観測記録に基づいて地震動強度の空間相関を検討した結果，離 間距離が約 $20 \mathrm{~km}$ 程度で弱くなる傾向が見られた。これは，既 往の研究成果とも整合的であった。

2）本手法により地震動強度の空間相関を考慮して, 内陸活断層の ような直下型地震の地震分布を確率的に評価する場合は, 評価 地域と活断層の配置によって相関距離の設定が結果の精度に 大きな影響を与える事に留意する必要がある。

3）本提案手法の地域防災への活用法として, 超過面積八ザードカ 一ブを用いて，地域に影響の与える地震を定量的に把握できる ことを示した。また，決定論的アプローチにより検討された神 奈川県の地震被害想定の地震シナリオの地震動ハザードにつ いて, 本手法を併用的に実施することで確率的な特性值を与え られることを示した。このような活用方策により，地域の想定 地震の設定に関する議論がより深まることが期待できる。

4）本結果は, 空間的な地震動分布を, 所与の地震動強度を超過す る面積というスカラー量で表現した。ベクトル空間的な情報を 活用し，ハザードマップとして表現する点は課題である。

本研究では, 評価対象地域で観測された地震記録に基づいて分析 を行ったため, 大地震については十分な量の地震データが得られな かった。そのため, 本研究で得られた結果の極めて大きな地震への 適用性については, 一層の検討が必要である。

今後は，観測記録の蓄積を待つとともに，このハザード解析手法 を用いて確率マップ表現を検討する。また，建物被害や人的被害な どのリスク評価手法へ展開することを検討する。

\section{謝辞}

本研究の実施に際し, 防災科学技術研究所の強震観測網と地震八 ザードステーションのデータを利用しました。また，神奈川県の地 震被害想定データを利用しました。(株) リスク工学研究所 福島誠 一郎博士には，地震動の空間相関に関する貴重なご意見をいただき ました。ここに記して謝意を表します。

\section{参考文献}

1) Central Disaster Management Council: Report on Earthquake and Tsunami Measures from the lessons learned from the Great East Japan Earthquake, 2011. 9 (in Japanese)

中央防災会議: 東北地方太平洋沖地震を教訓とした地震・津波対策に関 する専門調査会報告, 2011. 9

2) Cabinet Office: Basic Disaster Management Plan, 2018. 6 (in Japanese) 内閣府：防災基本計画, 2018. 6

3) Architectural Institute of Japan: AIJ Recommendations for Loads on Buildings (2015 Edition), 2015. (in Japanese) 日本建築学会：建築物荷重指針・同解説（2015），2015.

4) Hardy, G., Richards, J., Mauer, A., Kassawara, R.: U.S. Nuclear Power Industry Post-Fukushima Seismic Response Initiatives, SMiRT-23, 
Division VII, paper ID 435, 2015.

5) The Headquarters for Earthquake Research Promotion: National Seismic Hazard Maps for Japan (2018 Edition), 2018. 6 (in Japanese) 地震調查研究推進本部：全国地震動予測地図 2018 年版, 2018. 6

6) Atomic Energy Society of Japan (AESJ): Implementation Standard of Seismic Probabilistic Risk Assessment for Nuclear Power Plants, AESJ-SC-P006: 2015, 2015. (in Japanese)

日本原子力学会: 原子力発電所の地震を起因とした確率論的安全性評価 実施基準，日本原子力学会標準, AESJ-SC-P006: 2015, 2015.

7) Hayashi, T., Fukushima, S., Yashiro, H.: Effects of the Spatial Correlation between Ground Motion Intensities on the Seismic Risk of Portfolio of Buildings, Journal of Structural and Construction Engineering (Transactions of AIJ), No.600, pp. 203-210, 2006. 2 (in Japanese)

林孝幸, 福島誠一郎, 矢代晴実: 地震動強度の空間的な相関がポートフ オリオ地震リスクに与える影響, 日本建築学会構造系論文集, 第 600 号, pp. 203-210, 2006. 2

8) National Research Institute for Earth Science and Disaster Resilience: A Study on Evaluation Method of Seismic Risk of Japan, Technical Note of the National Research Institute for Earth Science and Disaster Resilience, No.415, 2018. (in Japanese)

防災科学技術研究所：全国を対象とした地震リスク評価手法の検討，防 災科学技術研究資料, No.415, 2018 .

9) Nojima, N., Kuse, M., Quang, L. D.: Mode Decomposition and Simulation of Strong Ground Motion Distribution Using Singular Value Decomposition, Journal of Japan Association for Earthquake Engineering. 2018, Vol. 18, No. 2, pp. 95-114, 2018. (in Japanese) 能島暢呂, 久世益充, Le Quang Duc: シナリオ地震動予測地図の特異值 分解によるモード分解と地震動分布のシミュレーション, 第 18 巻, 第 2 号, pp. 95-114, 2018.

10) Abe, Y., Yamamoto, H., Nakamura, M., Akiyama, S., Inoue, T.: Effect of Considering Spatial Correlation of Ground Motion Intensity on Seismic Damage Estimation, Journal of Japan Association for Earthquake Engineering. 2017, Vol.17, No.2, pp. 74-87, 2017. (in Japanese)

阿部雄太, 山本治貴, 中村雅紀, 秋山伸一, 井上哲也：地震動強さの距離 減衰式にみられるバラツキの相関が巨大地震の被害予測に与える影響, 日本地震工学論文集, 第 17 巻, 第 2 号, pp. 74-87, 2017.

11) National Research Institute for Earth Science and Disaster Resilience: K-NET and KiK-net, NIED Strong-Motion Seismograph Networks, http://www.kyoshin.bosai.go.jp/, (referenced on 2018-7-8)

防災科学技術研究所: 強震観测網 K-NET and KiK-net, http://www.kyoshin.bosai.go.jp/kyoshin/, （参照 2018-07-08)

12) Japan Metrological Agency: Monthly Earthquake Report (Catalog), http://www.data.jma.go.jp/svd/eqev/data/bulletin/hypo.html, (referenced on 2018-7-17) (in Japanese)

気象庁：地震月報（カタログ編）, http://www.data.jma.go.jp/svd/eqev/ data/bulletin/hypo.html, （参照 2018-7-17)

13) Japan Metrological Agency, CMT Solutions Catalog, http://www.da ta.jma.go.jp/svd/eqev/data/bulletin/cmt.html, (referenced on 2018-7 -19) (in Japanese)

気象庁: CMT 解データ, http://www.data.jma.go.jp/svd/eqev/data/bulle tin/cmt.html, （参照 2018-7-19)

14) National Research Institute for Earth Science and Disaster Resili ence, F-net, Broadband Seismograph Network, http://www.fnet.bos ai.go.jp/top.php?LANG=en, (referenced on 2018-7-19)

防災科学技術研究所: 広带域地震観測網 F-net, http://www.fnet.bosai.g o.jp/top.php，（参照 2018-7-19）

15) National Research Institute for Earth Science and Disaster Resilience: Improved Seismic Hazard Assessment after the 2011. Great East Japan Earthquake, Technical Note of the National Research Institute for Earth Science and Disaster Resilience, No.399, 2015. (in Japanese) 防災科学技術研究所：東日本大震災を踏まえた地震動ハザード評価の改 良, 防災科学技術研究資料, No.399, 2015.

16) Takemura, M.: Magnitude-Seismic Moment Relations for the Shallow Earthquakes in and around Japan, Journal of the Seismological
Society of Japan. 2nd ser., Vol.43, pp. 257-265, 1990. (in Japanese) 武村雅之: 日本列島およびその周辺地域に起こる浅発地震のマグニチュ ードと地震モーメントの関係, 地震 2, Vol.43, pp. 257-265, 1990.

17) Fujimoto, K., Midorikawa, S.: Relationship between Average ShearWave Velocity and Site Amplification Inferred from Strong Motion Records at Nearby Station Pairs, Journal of Japan Association for Earthquake Engineering. 2006, Vol.6, No.1, pp. 11-22, 2006. (in Japanese)

藤本一雄，翠川三郎：近接観測点ペアの強震記録に基づく地盤増幅度と 地盤の平均 $\mathrm{S}$ 波速度の関係, 日本地震工学会論文集, 第 6 巻, 第 1 号, pp. 11-22, 2006

18) Si, H., Midorikawa, S.,: New Attenuation Relationships for Peak Ground Acceleration and Velocity Considering Effects of Fault Type and Site Condition, Journal of Structural and Construction Engineering (Transactions of AIJ), No.523, pp. 63-70, 1999. 9 (in Japanese)

司宏俊，翠川三郎：断層タイプ及び地盤条件を考慮した最大加速度・最大 速度の距離減衰式, 日本建築学会構造系論文集, 第 523 号, pp. 63-70. 1999. 9

19) Midorikawa, S., Ootake, Y.: Empirical Analysis of Variance of Ground Motion Intensity in Attenuation Relationships, Journal of Japan Association for Earthquake Engineering. 2003, Vol.3, No. 1, pp. 59-70, 2003. (in Japanese)

翠川三郎，大竹雄：地震動強さの距離減衰式にみられるバラッキに関す る基礎的分析, 日本地震工学会論文集, 日本地震工学会論文集, 第 3 巻, 第 1 号, pp. 59-70, 2003.

20) Hayashi, T., Fukushima, S., Yashiro, H.: The Spatial Correlation between Ground Motion Intensities, Summaries of Technical Papers of Annual Meeting, Architectural Institute of Japan, B-II, pp. 43-44, 2006. 7 (in Japanese) 林孝幸，福島誠一郎，矢代晴実：地震動強度の空間的な相関について, 日本建築学会大会学術講演梗概集, B-II, pp. 43-44, 2006. 7

21) Yamazaki, F., Onishi, J., Tayama, S.: Development of Fragility Curves for Expressway Structures in Japan, Proc. 10th Japan Earthquake Engineering Symposium, Vol.3, pp. 3491-3496, 1998. (in Japanese) 山崎文雄, 大西淳一, 田山聡: 高速道路構造物に対する地震被害推定式 の提案, 第 10 回日本地震工学シンポジウム論文集, Vol.3, pp. 3491-3496, 1998.

22) Midorikawa, S., Fujimoto, K., Muramatsu, I.: Correlation of New J. M. A. Instrumental Seismic Intensity with Former J. M. A. Seismic Intensity and Ground Motion Parameters, Journal of Social Safety Science, Vol.1, pp. 51-56, 1999. (in Japanese) 翠川三郎，藤本一雄，村松郁栄：計測震度と旧気象庁震度および地震動 強さの指標との関係, 地域安全学会論文集, Vol.1, pp. 51-56, 1999

23) Fujimoto, K., Midorikawa, S.: Empirical Method for Estimating J.M.A. Instrumental Seismic Intensity from Ground Motion Parameters Using Strong Motion Records during Recent Major Earthquakes, Journal of Social Safety Science, No.7, pp. 214-246, 2005. (in Japanese) 藤本一雄, 翠川三郎：近年の強震記録に基づく地震動強さ指標による計 測震度推定法, 地域安全学会論文集, No.7, pp. 214-246, 2005.

24) Suetomi, I., Ishida, E., Isoyama, R.: A Procedure for High-Accuracy Map of Peak Ground Motion Using Observed Records, Proc. 28th JSCE Earthquake Engineering Symposium, CD-ROM, 2005. (in Japanese) 末冨岩雄，石田栄介，磯山龍二：空間補間による地震動分布推定の高精 度化のための一検討, 第 28 回地震工学研究発表会報告集, CD-ROM, 2005.

25) National Research Institute for Earth Science and Disaster Resili ence, J-SHIS, Japan Seismic Hazard Information Station, http://w ww.j-shis.bosai.go.jp/, (referenced on 2018-7-21)

防災科学技術研究所：J-SHIS 地震ハザードステーション, http://www. j-shis.bosai.go.jp/, （参照 2018-7-21)

26) Kanagawa Prefecture: Report of Earthquake Damage Assessment in Kanagawa Prefecture, 2015. 3 (in Japanese) 神奈川県：神奈川県地震被害想定調査報告書, 2015. 3 


\title{
PROPOSAL OF SPATIAL PROBABILISTIC SEISMIC HAZARD ANALYSIS AND THE APPLICATION TO THE DISASTER PREVENTION
}

\author{
Takayuki HAYASHI ${ }^{* 1}$ and Harumi YASHIRO*2 \\ ${ }^{* 1}$ Unit Leader, Property Risk Engineering Dept., Tokio Marine \& Nichido Risk Consulting Co., Ltd., M.Eng. \\ ${ }^{*}$ Prof., Dept. of Civil \& Environmental Engineering, School of Systems Engineering, National Defense Academy of Japan, Dr.Eng.
}

In earthquake risk management, it is important to conduct probabilistic seismic hazard analysis (PSHA) and determine the relationship between seismic hazard and probability. When evaluating seismic risk for a region, the spatial correlation of ground motion must be understood. In this study, we attempt a spatial PSHA with spatial correlation and correction based on earthquake observation records recorded in the target area.

To model the spatial correlation of the ground motion, we create an earthquake ground motion dataset from the records of K-NET and KiK-net operated by NIED. Ground motion intensity measures in the dataset is peak ground velocity on engineering bedrock which are based on the records observed in Kanagawa prefecture for the target site in this study. There are 1316 records by 196 earthquakes including the 2011 Tohoku great earthquake in the dataset. We model the spatial correlation statistically using the dataset. We calculate the residuals between actual and estimated ground motion of dataset and obtain the relationship between the correlation factors of residuals and the distances for pairs of observation stations. When calculating the residuals, we correct the predicted ground motion intensity by the empirical attenuation equation with correction factor for earthquakes and observation stations obtained from dataset analysis.

We apply the spatial correlation of ground motion and the correction at the observation points.to spatial PSHA. When conducting spatial PSHA, we employ Monte-Carlo simulation to determine the probabilistic characteristics of the spatial seismic hazard. First, we generate the samples of PGV on the engineering bedrock of the observation stations in consideration with spatial correlation and correction factor. Next, PGV of other places in the target area are interpolated with the PGV samples at observation stations by simple kriging method. Finally, we obtained PGV at ground surface by soil amplification factor calculated from VS30 and calculate JMA seismic intensity from PGV at ground surface. We repeat these calculation and aggregate into the hazard curve.

Trial application for Kanagawa prefecture is studied. Target is rectangle area including Kanagawa prefecture. There are 83 observation stations in the area. And, seismic source model and ground motion prediction model are followed The National Seismic Hazard Map for Japan. Results of spatial PSHA is expressed by hazard curve which shows relationship between the exceedance probability and area ratio exceeding to given ground motion intensity relative to the total area of Kanagawa pref. By comparison the results to the hazard estimation result in the earthquake damage assessment by Kanagawa pref., maximum possible earthquake for regional disaster planning are discussed based on the quantitative hazard results for the region. 